\title{
Abdominal compartment syndrome due to subcutaneous emphysema
}

\author{
Robert Reed, ${ }^{1}$ Franco D'Alessio, ${ }^{2}$ Lonny Yarmus, ${ }^{3}$ David Feller-Kopman ${ }^{3}$ \\ ${ }^{1}$ Pulmonary and Critical Care Medicine Department, University of Maryland, Baltimore, Maryland, USA; \\ 2Pulmonary and Critical Care Medicine Department, Johns Hopkins Hospital, Baltimore, Maryland, USA \\ ${ }^{3}$ Interventional Pulmonology Department, Johns Hopkins Hospital, Baltimore, Maryland, USA
}

Correspondence toDr Robert Reed, rreed@medicine.umaryland.edu

\section{DESCRIPTION}

A man in his late thirties presented with a 6 month history of fevers, dyspnoea, productive cough and an unintentional 50 pound weight loss. Evaluation revealed cavitating Hodgkin's lymphoma. During the hospital course, a percutaneous drain was placed into a large cavity of the left upper lobe. When the drain was later removed while the patient was undergoing mechanical ventilation, massive subcutaneous emphysema developed rapidly (figures 1 and 2A) due to a fistula at the drain site (figure 2A, red arrow). Bladder pressures rose to $26 \mathrm{~mm} \mathrm{Hg}$ with concomitant decline in urine output. Abdominal compartment

\section{Learning points}

- A percutaneous intrathoracic drain can lead to massive subcutaneous emphysema in a patient receiving positive pressure ventilator support.

- Massive subcutaneous emphysema can contribute to abdominal compartment syndrome.

- Decompression of massive subcutaneous emphysema can be accomplished through pressure release 'blowholes'.

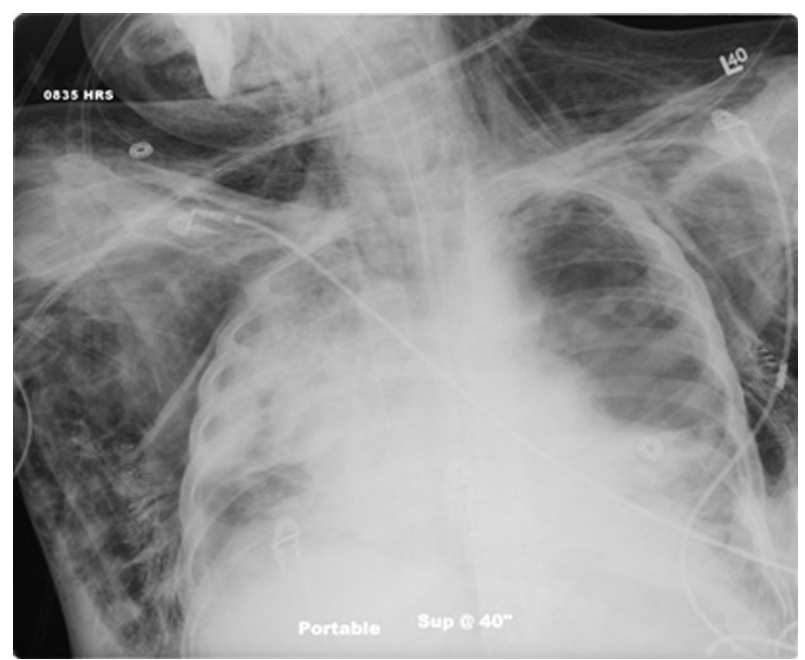

Figure 1 Antero-posterior radiograph demonstrating massive subcutaneous emphysema. syndrome (defined as organ dysfunction attributable to elevated intraabdominal pressures) was diagnosed. Four incisions were made to function as pressure release 'blowholes' with resulting rapid reduction in bladder pressures and improved urinary outflow (figure $2 \mathrm{~B}$ ).

Competing interests None.

Patient consent Not obtained.

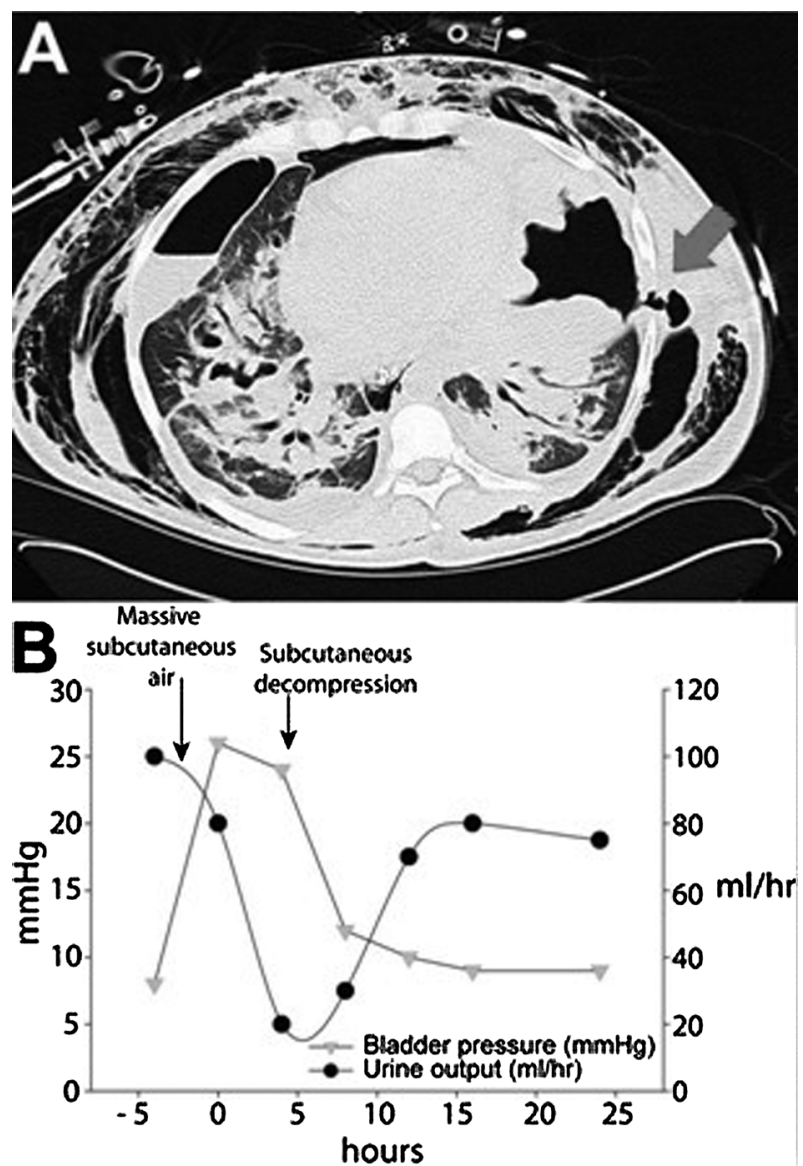

Figure 2 A) CT demonstrating fistula. B) Correlation of bladder pressure and urine output response to decompression of subcutaneous emphysema. 


\section{BMJ Case Reports}

This pdf has been created automatically from the final edited text and images.

Copyright 2012 BMJ Publishing Group. All rights reserved. For permission to reuse any of this content visit http://group.bmj.com/group/rights-licensing/permissions.

BMJ Case Report Fellows may re-use this article for personal use and teaching without any further permission.

Please cite this article as follows (you will need to access the article online to obtain the date of publication).

Reed R, D’Alessio F, Yarmus L, Feller-Kopman D. Abdominal compartment syndrome due to subcutaneous emphysema. BMJ Case Reports 2012; 10.1136/bcr.11.2011.5089, Published XXX

Become a Fellow of BMJ Case Reports today and you can:

- Submit as many cases as you like

- Enjoy fast sympathetic peer review and rapid publication of accepted articles

- Access all the published articles

- Re-use any of the published material for personal use and teaching without further permission

For information on Institutional Fellowships contact consortiasales@bmjgroup.com

Visit casereports.bmj.com for more articles like this and to become a Fellow

Keep up to date with all published cases by signing up for an alert (all we need is your email address) http://casereports.bmj.com/cgi/alerts/etoc 